\begin{tabular}{|c|c|c|c|c|}
\hline \multirow[b]{2}{*}{$\begin{array}{l}\text { I' concen- } \\
\text { tration } \\
\text { (p.p.m.) }\end{array}$} & \multirow[b]{2}{*}{$\begin{array}{c}\text { Ca concen- } \\
\text { tration } \\
\left(10^{-8} \mathrm{M}\right)\end{array}$} & \multicolumn{2}{|c|}{ Table 1} & \multirow[b]{2}{*}{$\begin{array}{l}P \text { in } \\
\text { turys } \\
\text { (mg) }\end{array}$} \\
\hline & & $\underset{\text { potential }}{\mathbf{P}}$ & $\begin{array}{l}\text { D.M. tops } \\
(\mathrm{g})\end{array}$ & \\
\hline 0.10 & $\begin{array}{r}3 \cdot 1 \\
16 \cdot 5\end{array}$ & $\begin{array}{l}6 \cdot 97 \\
6 \cdot 64\end{array}$ & $\begin{array}{l}0.347 \pm 0.027 \\
0.349 \pm 0.013\end{array}$ & $\begin{array}{l}0.32 \pm 0.017 \\
0.32 \pm 0.024\end{array}$ \\
\hline 0.50 & $\begin{array}{r}3 \cdot 1 \\
16 \cdot 5\end{array}$ & $\begin{array}{l}6.27 \\
5.94\end{array}$ & $\begin{array}{l}0.757 \pm 0.043 \\
0.707 \pm 0.010\end{array}$ & $\begin{array}{l}1.68 \pm 0.069 \\
1.45 \pm 0.045\end{array}$ \\
\hline $2 \cdot 50$ & $\begin{array}{r}3 \cdot 1 \\
16 \cdot 5\end{array}$ & $\begin{array}{l}5 \cdot 57 \\
5 \cdot 24\end{array}$ & $\begin{array}{l}1 \cdot 229 \pm 0.063 \\
1 \cdot 152 \pm 0.021\end{array}$ & $\begin{array}{l}5 \cdot 44 \pm 0.086 \\
5 \cdot 52 \pm 0 \cdot 100\end{array}$ \\
\hline
\end{tabular}

After 21 days of treatment the grass was cut, dried at $80^{\circ} \mathrm{C}$ and weighed. It was dry-ashed and analysed for phosphate by the vanadomolybdate mothod. The roots were not weighed or analysed.

The results in Table 1 show that where phosphate is the limiting growth factor a five-fold change in the concentration of calcium has no significant effect $(P=0.05)$ on the yield of dry matter. At the low and high phosphate levels the phosphate content of the leaves is not affected by the calcium concentration, but at 0.50 p.p.m. phosphorus it is significantly reduced $(P=0.05)$ by the high concentration of calcium. This latter result, which is conceivably due to precipitation of calcium phosphate, is in the opposite direction to that which would be predicted by the phosphate potential. It is, therefore, concluded that, with solutions of about the same composition is those in soil, it is the phosphate concentration and not the potential which determines phosphate uptake by plants, though it is not certain whether the concentration should be expressed as the total inorganic phosphate or as $\mathrm{H}_{2} \mathrm{PO}_{4}^{\prime}$ ions.

In analysing soils for soluble phosphate, ideally the soil solution should be used, but because the solution is difficult to obtain in sufficient amount for analysis the soil is sometimes shaken with a dilute solution of a calcium salt, for example, 0.01 $\mathrm{M} \mathrm{CaCl}_{2}$ (refs. 4 and 5). As an alternative this should be satisfactory so long as the soil solution itself is about $0.01 \mathrm{M}$ in calcium; but there seems no case for expressing the results as potentials when considering uptake by plants.

Department of Physiological Chemistry,

A. WILD

University of Reading.

${ }^{1}$ Schofield, R. K., Soils and Fert., 18, 373 (1955).

${ }^{2}$ Russell, E. W., Soil Conditions and Plant Growth, ninth ed. (Longman, 1961).

${ }^{3}$ Hewitt, E. J., Tech. Comm. No. 22. Commonwealth Bur. Hort. Plantation Crops (1952).

4Aslyng, H. C., Roy. Vet. and Agric. Coll. Yearbook, Copenhagen, 1 (1954). White, R. E., and Beckett, P. H. T., Plant and Soil, 20, 1 (1964).

\section{Effect of Chemical Weathering on Parent Material}

THE summary by Keller ${ }^{2}$ indicates that little progress has been made recently in the qualitative assessment of chemical weathering, since the equations of soil property by Jenny ${ }^{2}$ and weathering rate by Jackson et al. ${ }^{8}$ have not been developed. Recently, Loughnan ${ }^{4}$ discussed soveral important aspects of weathering; but his paper is neither complete in itself nor intimately related to the main equations. The purpose of this communication is to elaborate on the last variable, 'parent material', in the equation of Jenny ${ }^{2}$ with the aid of the recent data of Bayliss and Loughnan ${ }^{5,6}$, Craig 7 , Loughnan and Bayliss ${ }^{8}$, snd Loughnan et al..$^{2,10}$.

The variable of 'parent material' is subdivided into three factors: first, porosity and pormeability-the quantity of fluid able to enter and flow through a rock; secondly, surface area-the extent of the area, which the fluid may attack; and thirdly, mineral structure-the susceptibility of the minerals in a rock to chemical weathering. The factor, 'mineral structure', is equivalent to the 'leaching index number' of Jackson et al. ${ }^{3}$ and the 'persistence series' of Pettijohn ${ }^{11}$. These series are consistent with the results obtained from an approximately neutral oxidizing environment, although important exceptions are noted if the prevailing habitat is either acid $(p H 4)$ or alkaline $(p \mathrm{H} 10)$, especially if the conditions are reducing rather than oxidizing.

To account for these exceptions in the equation the factor 'mineral structure' is further subdivided into the components of bonding energy, solubility, electrostatic stability and steric hindrance. The bonding energy for each of the main silicate groups, which is essentially controlled by the percentage of the strong silicon to oxygen bonds, has been calculated by Keller ${ }^{12}$. This series is shown by Keller' to be similar to the stability series of Goldich, the order of crystallization by Rosenbush, the reaction series of Bowen and the classification of silicates by Strunz. The second component, solubility, which is markedly affected by both the $p H$ and $E h$, is taken from a solubility product. If, however, this information is unavailable, then the ionic potential of Goldschmidt ${ }^{13}$ gives an approximate value. This factor is important because it controls the differential movement of the various ions after release from the structuro. Electrostatic stability of a crystal, the third component, depends on the local distribution of charge, which is a resultant of the intensity and position of the individual atoms. Any charge concentration will provide a nucleus for chemical attack. The fourth component, steric hindrance, is created by the structural configuration. A framework structure traps a highly mobile ion compared with that of an open structure.

An example of chemical weathering, that is, illite compared with vermiculite (another 2:1 layer lattice silicate), is taken to illustrate the four components of the factor 'mineral structure'. First, from Keller 12, the bonding between oxygen and aluminium in illite is stronger than that between oxygen and magnesium or ferrous iron in vermiculite. Secondly, from Loughnan the aluminium in illite is less soluble than the magnesium or ferrous iron in vermiculite. Thirdly, the interlatered cation is shown by Bassett ${ }^{14}$ to occupy a more stable electrostatic environment in illite compared with vermiculite. The fourth and final feature is the more difficult penetration of percolating fluids through the gap between the $2: 1$ layers of $1 \AA$ in illite compared with $5 \AA$ in vermiculito.

School of Applied Geology,

University of New South Wales, Sydney.

${ }^{1}$ Keller, W. D., The Principles of Chemical Weathering (Lucas Bros., Missouri, 1957).

${ }^{2}$ Jenny, H., Factors of Soil Formation (McGraw-Hill, 1941).

${ }^{3}$ Jackson, M. L., Tyler, S. A., Wills, A. L., Bourbeau, G. A., and Penningtor, R. P., J. Phys. Coll. Chem., 52,1237 (1948).

4 Loughnan, F. C., J. Sediment. Petrol., 32, 284 (1962).

${ }^{\circ}$ Bayliss, P., and Loughnan, F. C., Amer. Min., 48, 410 (1963).

- Bayliss, P., and Loughnan, F. C., Clay Min. Bull. (In the press).

${ }^{7}$ Craig, D. C., M.Sc. thesis, Univ. N.S.W. (1963).

soughnan, F. C., and Bayliss, P., Amer. Min., 46, 209 (1961).

Loughnan, F. C., Grim, R. E., and Vernet, J., J. Geol. Soc. Austral., 8 , $245(1962)$.

${ }^{10}$ Loughnan, F. C., Ko Ko, M., and Baylise, P., J. Geol. Soc. Austral. (in the press).

${ }^{11}$ Pettijohn, F. J., Sedimentary Rocks (Harper and Bros., 1957).

${ }^{22}$ Keller, W. D., Amer. Min., 39, 783 (1954).

${ }^{12}$ Goldschmidt, V. M., J. Chem. Soc., 655 (1937)

14 Bassett, W. A., Bull. Geol. Soc., "71, 449 (1960).

\section{PSYCHOLOGY}

\section{Taste Sensitivity and Food Deprivation, Blood Sugar Level and Composition of Meal}

Is a recent communication, Berg et al. ${ }^{1}$ cite Dell ${ }^{2}$ that "a hungry animal is considered to be in a state of high nervous irritability leading to a heightened level of sensory and motor excitation. As glycogen stores are depleted, blood glucose levels decrease, cireulating epinephrine rises and stimulates the reticular formation of the brain, which in turn produces cortical arousal and facilitation of motor 